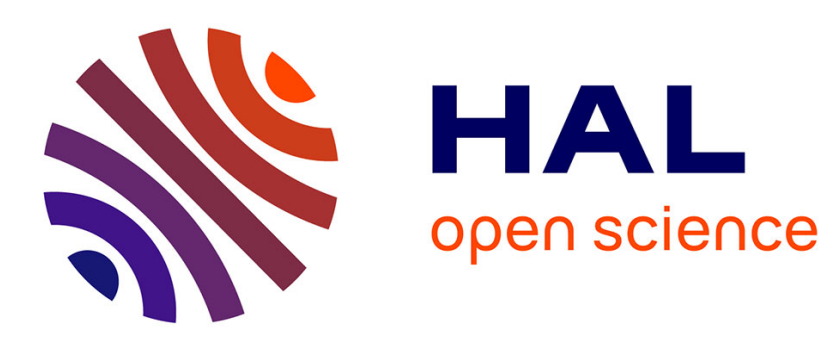

\title{
Effects of rotation length on the grade recovery and wood properties of Sitka spruce structural timber grown in Great Britain
}

John Moore, Andrew Lyon, Lehneke

\section{- To cite this version:}

John Moore, Andrew Lyon, Lehneke. Effects of rotation length on the grade recovery and wood properties of Sitka spruce structural timber grown in Great Britain. Annals of Forest Science, 2012, 69 (3), pp.353-362. 10.1007/s13595-011-0168-x . hal-00930738

\section{HAL Id: hal-00930738 \\ https://hal.science/hal-00930738}

Submitted on 1 Jan 2012

HAL is a multi-disciplinary open access archive for the deposit and dissemination of scientific research documents, whether they are published or not. The documents may come from teaching and research institutions in France or abroad, or from public or private research centers.
L'archive ouverte pluridisciplinaire HAL, est destinée au dépôt et à la diffusion de documents scientifiques de niveau recherche, publiés ou non, émanant des établissements d'enseignement et de recherche français ou étrangers, des laboratoires publics ou privés. 


\title{
Effects of rotation length on the grade recovery and wood properties of Sitka spruce structural timber grown in Great Britain
}

\author{
John R. Moore • Andrew J. Lyon • Stefan Lehneke
}

Received: 20 March 2011 / Accepted: 15 November 2011 /Published online: 6 December 2011

(C) INRA / Springer-Verlag France 2011

\begin{abstract}
- Context Rotation length is known to affect timber quality in many plantation species, but its effect on the properties of Sitka spruce (Picea sitchensis) structural timber has not been quantified.

- Aim Te purpose of this study was to compare selected wood properties and grade recovery of Sitka spruce structural timber cut from different radial positions within a log reflecting different cambial ages.

- Methods Structural timber was sawn from 60 logs harvested from an 83-year-old stand in Great Britain. Five specimens were tested from each log: four from consecutive
\end{abstract}

Handling Editor: Barry Alan Gardiner

Contribution of co-authors John Moore initiated the study, undertook field and laboratory measurements, analysed the data and wrote the final paper.

Andrew Lyon assisted with developing the methodology for the study, organised the fieldwork and timber processing in the sawmill, assisted with field and laboratory measurements and contributed to the final report.

Stefan Lehneke assisted with the laboratory measurements and contributed to the final report.

J. R. Moore · A. J. Lyon · S. Lehneke

Forest Products Research Institute, Edinburgh Napier University, Edinburgh EH10 5DT, UK

\section{Present Address:}

J. R. Moore $(\bowtie)$

Scion,

Private Bag 3020, Rotorua 3046, New Zealand

e-mail: john.moore@scionresearch.com

\section{Present Address:}

A. J. Lyon

Department of Agriculture and Food,

South Perth, WA 6151, Australia radial positions out from the pith and the fifth a random selection from outside the innermost 15 rings.

- Results Mean modulus of elasticity and bending strength of timber from the outermost radial position were 51\% and $41 \%$ greater, respectively, than for timber from adjacent to the pith. Wood density differed by $9 \%$ between these positions. The amount of distortion (spring, twist and bow), knot frequency and total knot area was significantly higher in timber cut from adjacent to the pith.

- Conclusion Whilst longer rotations result in timber with improved mechanical properties and less distortion, economic and windthrow considerations may limit their implementation in Great Britain.

Keywords Sitka spruce $\cdot$ Rotation length $\cdot$ Wood properties $\cdot$ Structural timber $\cdot$ Distortion

\section{Introduction}

Sitka spruce (Picea sitchensis (Bong.) Carr.) is the most commonly planted conifer species in Great Britain (Forestry Commission 2010) and is the main commercial species processed by the sawmilling and panel board industries in this country. Structural timber produced from British-grown Sitka spruce trees normally meets the requirements for the C16 strength class (a general-purpose structural timber used in applications such as stud walls), as defined in EN 338 (CEN 2009), and yields of C16 timber in excess of 90\% are generally obtained when timber is machine strength graded. However, yields of higher strength class timber that is better suited to more demanding applications, such as trussed rafters and lintels, are generally very low so that it is uneconomic to try to segregate out such material during the strength grading process. One reason for the lack of higher 
strength class timber could be the rotation length that Sitka spruce plantations are managed over in Great Britain. Rotation length affects not only the financial return from forest management but also the quality of timber produced, with longer rotations generally having a positive effect on timber properties (Cown and McConchie 1982; Bilbis et al. 1993; Clark et al. 1996; Johansson et al. 2001; Duchesne 2006; Walker 2006). In Britain, rotation lengths of 35-45 years are common for Sitka spruce stands, and in many cases, the move to shorter rotations is driven by concerns about stand stability on exposed upland sites (Miller 1985; Macdonald and Hubert 2002). On the other hand, there is also an increasing move to transform even-aged, single-species stands into continuous cover forests with more diverse and irregular structures (Macdonald et al. 2010). Such stands may contain a number of older and larger trees.

At present, there are no data available on the properties of Sitka spruce structural timber cut from older stands in Britain with which to test these hypotheses about the effects of rotation length. In an earlier study using material from a Sitka spruce spacing trial planted in 1935 at Glengarry in western Scotland, measurements were only made on discs and small defect-free specimens cut from the trees and mechanical testing of structural timber was not undertaken (Forest Research, unpublished data). Therefore, predictions about the effects of rotation length on the physical and mechanical properties of Sitka spruce structural timber are currently based on our knowledge of the intra-tree variation in wood properties. This variation has been studied for a large number of species, and much of the work in this field has been summarised in review papers (e.g. Zobel and Sprague 1998; Larson et al. 2001; Lachenbruch et al. 2011). In many conifer species, including Sitka spruce, there is a general increase in wood density from the pith to the bark and a reduction in the angle of cellulose microfibrils in the secondary cell wall (microfibril angle, MFA). As many mechanical properties (e.g. bending strength and modulus of elasticity) are related to density and MFA (Evans and Ilic 2001; McLean et al. 2010), they also exhibit an increase from pith to bark. Similarly, intra-tree variation in timber distortion can be linked to age-related variation in wood properties, such as spiral grain angle, ring curvature and MFA (e.g. Johansson et al. 2001; Cown et al. 2002; Ormarsson and Cown 2005). Wood found within the first 10 or 20 rings (for Sitka spruce, Brazier and Mobbs 1993 suggest 12 rings) from the pith is generally referred to as core wood (or juvenile wood), whilst wood in the remainder of the cross-section is referred to as outer wood (or mature wood; Zobel and Sprague 1998; Larson et al. 2001). Therefore, predictions about the effect of rotation length on wood properties are often based on the relative proportions of juvenile and mature wood in the stem. For example, Macdonald and Hubert (2002) calculated that the proportion of juvenile wood (expressed as a percentage of basal area) in a 35-year-old Sitka spruce stand of yield class 12 (i.e. maximum mean annual volume increment of $12 \mathrm{~m}^{3} \mathrm{ha}^{-1}$ year $^{-1}$ ) was approximately $40 \%$. At age 60 years, the proportion of juvenile wood decreased to $<20 \%$.

In stands grown on 35- to 45 -year rotations, a combination of tree size and cutting patterns used by British sawmills tends to result in a large proportion of structural timber being cut from the juvenile core of the tree. On many sites, concerns about wind damage have resulted stands being managed on a no-thin regime (Miller 1985), which has led to a reduced proportion of mature wood. However, in older stands, the combination of increased tree diameter and greater proportion of mature wood means that it should be possible to cut pieces of structural timber which are entirely composed of higher stiffness mature wood. Based on existing knowledge of radial variation in wood properties, it is expected that timber cut from the mature wood of older and larger trees would have superior physical and mechanical properties and would be less prone to twisting when dried (Perstorper et al. 1995; Johansson et al. 2001). This, in turn, could mean that an acceptable percentage could meet the requirements for higher strength classes, e.g. C24 and possibly C27. Therefore, it may be possible for local sawmills to supply a sector of the structural timber market which is currently almost exclusively supplied by imported timber.

In the study reported here, selected physical and mechanical properties were measured for timber cut from an 83-year-old stand of Sitka spruce growing at an upland site in Great Britain. Results from mechanical tests conducted on structural timber cut from different radial positions within the sampled trees are presented and the following hypotheses are tested: (1) the mechanical properties of timber cut from the mature wood zone of the tree will be superior to those of timber cut from the juvenile wood zone; (2) a significantly higher proportion of timber cut from the mature wood zone of each log will meet the requirements for higher strength classes than from the juvenile wood zone; and (3) timber from the mature wood zone will have lower amounts of distortion and a lower knot volume.

\section{Materials and methods}

\subsection{Site description}

The study was undertaken in Birkley Wood, which is locat-

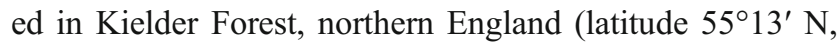
longitude $2^{\circ} 21^{\prime} \mathrm{W}$; elevation, $230 \mathrm{~m}$ a.s.l.). The soil at this site is a peaty gley derived from Carboniferous sediments, with a peat layer of 10-20 cm, and clayey subsoil, which results in it being poorly drained. Birkley Wood is 1.9 ha in extent and was planted in 1923, as a Sitka spruce/Scots pine (Pinus sylvestris L.) mixture at a spacing equivalent to 6,719 trees per hectare; this type of 50:50 mixture was 
common in the early phase of upland afforestation in Great Britain. Prior to planting, the site received minimal cultivation and surface drainage, and this is in marked contrast to the closely spaced ploughing used in much subsequent afforestation in the region. Routine crop survey recorded a mean height of $10 \mathrm{~m}$ for the Sitka spruce at age 23 and top height of $18 \mathrm{~m}$ at age 40 and $24 \mathrm{~m}$ at age 51 . The stand was given a low thinning in 1960, and approximately $290 \mathrm{~m}^{3}$ of timber was removed. Since 1987, the stand dynamics of Birkley Wood have been closely monitored, and each tree is numbered and its relative position has been recorded (Quine and Malcolm 2007). The surrounding stands were felled in 2006, which increased the degree of wind exposure for Birkley Wood, and it was extensively damaged by a storm on 31st December 2006.

\subsection{Forest and sawmill measurements}

In May 2007, 30 trees covering the range of diameters present were selected for conversion into sawn timber. The diameter at breast height (1.3 $\mathrm{m}$ above ground level) of the sampled trees ranged from 34.0 up to $84.5 \mathrm{~cm}$, with a mean of $53.2 \mathrm{~cm}$. Edge trees with very coarse branching were deliberately avoided. A previous study by Mochan and Connolly (2006) showed that there are no detrimental effects on mechanical and physical wood properties of wind-damaged trees until they have been lying on the ground for at least 18 months. Therefore, both standing and wind-damaged trees were sampled; the final sample included 19 wind-damaged (uprooted) trees and 11 standing trees. The mean height of standing trees was $37.2 \mathrm{~m}$. Each standing tree had a north line and a breast height band painted on it prior to felling, whilst wind-damaged trees had a line painted on their top side and their direction of fall was recorded. Two 3-m logs were cut from each tree. Because the site had been a Ministry of Defence firing range during World War 2, the butt end of the lower log was located at $1.8 \mathrm{~m}$ above the ground to reduce the risk of encountering bullets in the logs during processing at the sawmill. This choice of log height may have meant that the lowest stiffness part of the tree (Xu and Walker 2004) was not sampled.

The length and end diameters over bark of each log were recorded; small end (top) diameters of the 60 logs ranged from 261 up to $771 \mathrm{~mm}$, with a mean of $456 \mathrm{~mm}$. Logs were then marked with a unique paint colour and stamp combination so that they could be linked to the tree they were cut from. The innermost 15 annual rings (i.e. the juvenile core) were identified and marked on each log along with the 30th, 45th and 60th rings. The logs were then transported to the Ladywell sawmill at Kirriemuir, Scotland, where they were sawn using a cutting pattern that maximised the yield of $47 \times 100 \mathrm{~mm}$ timber. These cutting patterns yielded structural timber from the innermost part of the logs, which is normal practice in British sawmills. In total, 1,365 pieces of structural timber with these dimensions were cut and each piece was uniquely numbered so that it could be linked to the tree and log that it came from. This timber was then kilndried to $18 \%$ moisture content and machine strength graded using a GoldenEye-702 X-ray grader (MiCROTEC, Brixen, Italy). The value of the indicating property (IP value) determined by the grading machine was recorded for each piece of timber; from this, the amount of timber passing at C16 and $\mathrm{C} 24$ was determined. Resources did not allow for all pieces to be mechanically tested in the laboratory. Therefore, a sample consisting of five pieces of timber from each $\log (300$ pieces in total) was selected for destructive testing to determine the modulus of elasticity and modulus of rupture in bending. Four of these pieces were selected from consecutive radial positions starting from the pith, whilst the fifth was randomly selected from outside the juvenile core (Fig. 1). All 300 pieces selected for further testing were flatsawn and had their annual rings orientated approximately parallel to the major axis of the board.

\subsection{Laboratory measurements}

Prior to testing, the timber was stored in a controlled environment $\left(20^{\circ} \mathrm{C}\right.$ and $65 \%$ relative humidity) at Edinburgh Napier University until it reached constant mass. A subsample consisting of those pieces of timber from radial positions 1 and 4 (i.e. closest to and furthest from the pith, respectively) was selected for more detailed assessment of knots and distortion. A three-dimensional profile of each piece of timber was obtained using the Freiburg Improved Timber Scanner (Seeling and Merforth 2000). From these profiles, the maximum amount of spring, twist and bow over a 2-m

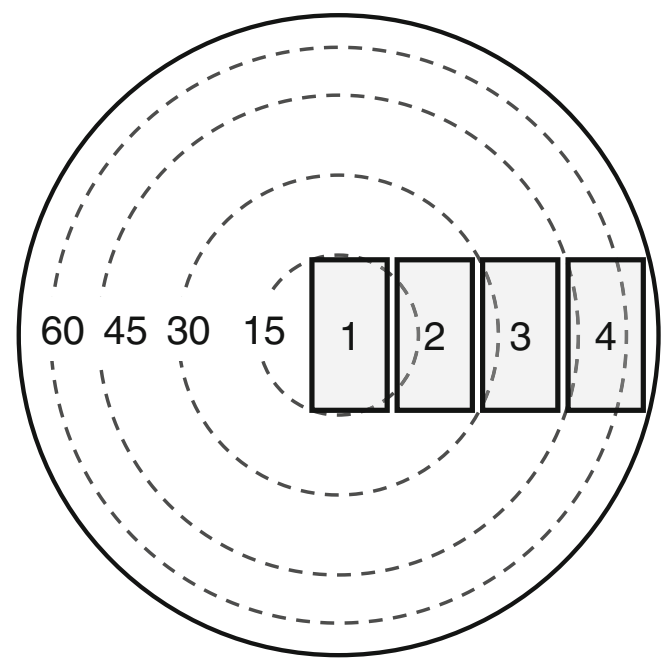

Fig. 1 Schematic diagram showing the approximate locations of timber from radial positions 1 to 4 . The location of annual rings $15,30,45$ and 60 were painted on the ends of each log sampled 
interval within each piece of timber was calculated in accordance with EN1310 (CEN 1997) using a software programme written specifically for this task. Each piece of timber from the bottom log in this subsample was photographed on all four longitudinal faces and the size and location of all knots $>5 \mathrm{~mm}$ in diameter determined from these photographs using image analysis software (Qwin, Leica Microsystems, Wetzlar, Germany). Overall, distortion measurements were made on 120 pieces of timber and knot characteristics were measured on 60 pieces.

Four-point bending tests were conducted on each of the 300 pieces of timber using a Zwick Z050 universal testing machine (Zwick Roell, Ulm, Germany). Tests were performed in accordance with the procedures described in EN 408:2003 (CEN 2003) and EN384:2010 (CEN 2010a), with the exception that the critical section was not located in the central portion of the test span. Global modulus of elasticity $\left(\mathrm{MOE}_{\mathrm{G}}\right)$ and modulus of rupture were calculated from the data obtained during these tests using the equations given in EN 408 (CEN 2003). Following testing, a 40-mm-thick subsample spanning the full cross-section of the specimen was cut. These samples were weighed immediately and their volume determined from dimensional measurements. Samples were then dried in an oven at $103^{\circ} \mathrm{C}$ for $72 \mathrm{~h}$ and the moisture content calculated from gravimetric measurements in accordance with EN 13183-1 (CEN 2002). Bulk density (i.e. mass of wood per unit volume at ambient moisture content) was calculated from measurements of sample mass and volume in accordance with ISO 3131 (ISO 1975). In addition, the average ring width was determined for these samples using the method described in EN1310 (CEN 1997).

\subsection{Data analysis}

Following the procedures described in EN 384 (CEN 2010a), values of $\mathrm{MOE}_{\mathrm{G}}$ and bulk density were adjusted to a $12 \%$ moisture content basis, whilst values of bending strength were adjusted to a $150-\mathrm{mm}$ nominal depth. An equivalent pure bending modulus of elasticity $\left(\mathrm{MOE}_{\mathrm{PB}}\right)$ was calculated from $\mathrm{MOE}_{\mathrm{G}, 12}$ (i.e. $\mathrm{MOE}_{\mathrm{G}}$ adjusted to $12 \%$ moisture content) using the following equation presented in EN 384:

$\mathrm{MOE}_{\mathrm{PB}}=1.3 \mathrm{MOE}_{\mathrm{G}, 12}-2.69\left(\mathrm{kNmm}^{-2}\right)$

Data were analysed using the open-source statistical package R (R Project Core Team 2010). Linear regression was used to investigate the relationships between modulus of rupture, modulus of elasticity $\left(\mathrm{MOE}_{\mathrm{PB}}\right)$ and density at $12 \%$ moisture content. A linear mixed-effects model (Pinheiro and Bates 2000) was used to compare density, $\mathrm{MOE}_{\mathrm{PB}}$, modulus of rupture (MOR), distortion and knot measurements between radial positions. A nested structure was assumed for the random effects of $\log$ and tree in accordance with the experimental design. The following model was fitted to data from the measurements on the structural timber:

$y_{i j k l}=\mu+\tau_{i}+h_{j}+T_{k}+L_{l(k)}+e_{i j k l}$

where $y_{i j k l}$ is the measurement of basic density, $\mathrm{MOE}_{\mathrm{PB}}$, MOR or distortion on an individual specimen; $\mu$ is the overall mean; $\tau_{i}$ is the fixed effect of the $i$ th radial position $(i=1,2,3,4) ; \mathrm{h}_{j}$ is the fixed effect of the $j$ th $\log (j=1,2) ; T_{k}$ is the random effect of the $k$ th tree $\left(\sim N\left(0, \sigma_{T}^{2}\right)\right) ; L_{l(k)}$ is the random effect of the $l$ th $\log$ within the $k$ th tree $\left(\sim N\left(0, \sigma_{\mathrm{L}}^{2}\right)\right.$; and $e_{i j k l}$ is the within-group error $\left(\sim N\left(0, \sigma_{\mathrm{e}}^{2}\right)\right.$. Differences between radial positions were examined using $F$ tests, and all tests were made at $\alpha=0.05$ level of significance. Linear contrasts were used to make specific comparisons in timber properties between radial positions. In particular, radial positions 2, 3 and 4 were compared with position 1, and positions 1 and 2 were compared with positions 3 and 4 . The same approach was used to compare values of spring, twist and bow between radial positions 1 and 4 , whilst the random effect of $\log$ was removed for the analysis of knot characteristics. In all cases, the assumptions of linear models, particularly those relating to homogeneity of variances, were tested and, where appropriate, transformations were made.

The characteristic values (i.e. the value that corresponds to a particular statistic of the probability distribution for the property of interest) of modulus of elasticity, bending strength and density for radial positions 1 to 4 were calculated using the procedures described in EN384 (CEN 2010a). The characteristic value for modulus of elasticity was equal to the mean value of $\mathrm{MOE}_{\mathrm{PB}}$, whilst characteristic values for density and bending strength were calculated from the 5th percentile values of MOR (adjusted to a 150 mm timber depth) and density. In accordance with EN384, a sample size adjustment was applied to the 5th percentile values of MOR. On the basis that 60 pieces of timber were sampled from each radial position, these 5 th percentile values were multiplied by 0.8 (i.e. $k_{\mathrm{s}}=0.8$ ). Because the timber had been machine strength graded, the 5 th percentile values were also multiplied by 1.12 to reflect the lower variability of machine-graded timber (i.e. $k_{v}=1.12$ ). Using these characteristic values, timber was assigned to a strength class based on the requirements given in EN338 (CEN 2009). Provided that the characteristic values of bending strength and density for a particular strength class were met, the characteristic value for bending stiffness only needed to exceed $95 \%$ of the required value for that strength class. The differences in these characteristic values and the resulting strength grade between radial positions were compared. 
The potential yields of different strength classes of timber were determined by calculating the optimum grade that each piece of timber could be assigned following the approach presented in EN 14081-2 (CEN 2010b). All 300 pieces of timber were included in this analysis, and the optimum yields were determined for all strength classes from $\mathrm{C} 16$ up to C27 as well as TR26 (a grade, used in Great Britain, for trussed rafters). For each strength class of interest, pieces of timber were ranked according to their value of $\mathrm{MOE}_{\mathrm{PB}}$ and assigned to the optimum grade. Characteristic values of bending strength $\left(f_{m, k}\right)$, modulus of elasticity $\left(E_{0, \text { mean }}\right)$ and density $\left(\rho_{k}\right)$ were calculated for each grade according to EN 384 , and checks were made to verify that these characteristic values satisfied the requirements for each grade. The effect of rotation length was simulated by removing pieces of timber from radial positions 3 and 4 from the analysis and recalculating the optimum yields. Timber from radial positions 1 and 2 would be more typical of that produced from stands grown on 35- to 45 -year rotations.

\section{Results}

\subsection{Timber mechanical properties}

Of the 1,365 pieces of timber that were strength graded with the GoldenEye-702, 1,359 (99.4\%) passed at C16 whilst $437(32.0 \%)$ passed at $\mathrm{C} 24$. For the sample of 300 pieces tested in the laboratory, values of $\mathrm{MOE}_{\mathrm{PB}}$ ranged from 3.77 up to $15.63 \mathrm{kN} \mathrm{mm}^{-2}$, with a mean of $9.41 \mathrm{kN} \mathrm{mm}^{-2}$ (Table 1). $\mathrm{MOE}_{\mathrm{PB}}$ was only weakly related to density $\left(R^{2}=0.23\right)$. Values of MOR ranged from 11.71 up to $74.97 \mathrm{Nmm}^{-2}$ and were moderately related to $\operatorname{MOE}_{\mathrm{PB}}\left(R^{2}=\right.$ $0.61)$, but only weakly related to wood density $\left(R^{2}=0.20\right)$.

There were significant differences in density (adjusted to a $12 \%$ moisture content), MOR and $\mathrm{MOE}_{\mathrm{PB}}\left(E_{0 \text {,mean }}\right)$ between radial positions $(p<0.001)$. Timber from positions 2 , 3 and 4 had significantly higher values of $\mathrm{MOE}_{\mathrm{PB}}$ and MOR than timber from position 1 (Table 2); however, only timber from positions 3 and 4 had significantly higher values of density. Not unexpectedly, the contrasts comparing density, bending strength and $\mathrm{MOE}_{\mathrm{PB}}$ for positions 1 and 2 with positions 3 and 4 were all significant $(p<0.001)$. There was no effect of $\log$ position on either $\mathrm{MOE}_{\mathrm{PB}}$ or density $(p=0.34$ and $p=0.63$, respectively); however, there was suggestive but inconclusive evidence that timber cut from the upper log had lower bending strength than timber cut from the lower $\log (p=0.07)$. Characteristic values of bending strength, stiffness and density increased from radial position 1 through to radial position 4 . Timber cut from radial position 1 met the requirements for the lower $\mathrm{C} 14$ strength class, whilst timber from radial position 4 met the requirements for the higher $\mathrm{C} 24$ strength class.

Mean ring width of timber decreased from $4.4 \mathrm{~mm}$ at radial position 1 to $2.5 \mathrm{~mm}$ at radial position 4 (Table 2). There was a moderate relationship between ring width (RW) and $\operatorname{MOE}_{\mathrm{PB}}\left(R^{2}=0.49\right.$; Fig. 2$)$. The nonlinear equation for the best fit line shown in Fig. 2 is given by:

$\operatorname{MOE}_{P B}=\frac{24.22}{1+e^{0.67 \mathrm{RW}}}+6.41$

Equations with a similar form were fitted to MOR and density, but were only able to explain a smaller proportion of the total variation in these two properties $\left(R^{2}=0.32\right.$ and $R^{2}=0.25$, respectively).

\subsection{Optimal grading}

For the dataset containing all 300 pieces of timber, there was a $100 \%$ yield at strength classes up to and including C20 (Table 3). Optimal yields for C24 and TR26 were above $70 \%$, whilst the yield for $\mathrm{C} 27$ was above $60 \%$. For these three higher strength classes, it was possible to assign the reject material to a lower strength class (either $\mathrm{C} 14$ or $\mathrm{C} 16$ ), which resulted in an overall yield of structural timber in excess of $85 \%$. When timber from radial positions 3 and 4 was excluded from the analysis, the yields of higher strength class timber decreased by approximately $20 \%$. The reduced percentage timber assigned to higher strength classes improved the overall yield for the strength class combinations

Table 1 Summary of the physical and mechanical properties of the 300 pieces of structural timber that were destructively tested

\begin{tabular}{lllll}
\hline Property & Minimum & Maximum & Mean & CoV (\%) \\
\hline MOE $_{\mathrm{G}, 12}\left(\mathrm{kN} \mathrm{mm}^{-2}\right)$ & 4.97 & 14.10 & 9.30 & 20.5 \\
MOE $_{\mathrm{PB}}\left(\mathrm{kN} \mathrm{mm}^{-2}\right)$ & 3.77 & 15.63 & 9.41 & 26.4 \\
MOR $\left(\mathrm{N} \mathrm{mm}^{-2}\right)$ & 11.71 & 74.97 & 41.20 & 26.9 \\
Density $\left(\mathrm{kg} \mathrm{m}^{-3}\right)$ & 331 & 558 & 426 & 11.1 \\
\hline
\end{tabular}

Values of density and global modulus of elasticity $\left(\mathrm{MOE}_{\mathrm{G}, 12}\right)$ are adjusted to $12 \%$ moisture content; MOR is adjusted to a $150-\mathrm{mm}$-deep section. Pure bending modulus of elasticity $\left(\mathrm{MOE}_{\mathrm{PB}}\right)$ was calculated using Eq. 1

$\mathrm{CoV}$ coefficient of variation 
Table 2 Comparison of the properties of timber from different radial positions

\begin{tabular}{|c|c|c|c|c|c|c|}
\hline \multirow[t]{2}{*}{ Property } & \multicolumn{6}{|c|}{ Radial positions } \\
\hline & 1 & 2 & 3 & 4 & 1 and 2 & 3 and 4 \\
\hline Ring width (mm) & 4.4 & $3.9^{*}$ & $3.2 * * *$ & $2.5^{* * *}$ & 4.1 & 2.8 \\
\hline $\operatorname{MOR}\left(\mathrm{N} \mathrm{mm}^{-2}\right)$ & 33.9 & $39.3^{* * *}$ & $43.7 * * *$ & $47.8 * * *$ & 36.6 & 45.6 \\
\hline Density $\left(\mathrm{kg} \mathrm{m}^{-3}\right)$ & 414 & $415 \mathrm{~ns}$ & $425 *$ & $451 * * *$ & 414 & 438 \\
\hline$E_{0, \text { mean }}\left(\mathrm{kN} \mathrm{mm}^{-2}\right)$ & 7.18 & $9.04 * * *$ & $10.08 * * *$ & $10.83 * * *$ & 8.11 & 10.45 \\
\hline$f_{m, k}\left(\mathrm{~N} \mathrm{~mm}^{-2}\right)^{\mathrm{a}}$ & 14.7 & 17.3 & 17.9 & 23.6 & 17.0 & 19.1 \\
\hline$\rho_{k}\left(\mathrm{~kg} \mathrm{~m}^{-3}\right)^{\mathrm{a}}$ & 335 & 337 & 352 & 373 & 337 & 361 \\
\hline Strength class & $\mathrm{C} 14$ & $\mathrm{C} 18$ & $\mathrm{C} 20$ & $\mathrm{C} 24$ & $\mathrm{C} 16$ & $\mathrm{C} 20$ \\
\hline
\end{tabular}

The characteristic values for stiffness, bending strength and density are given by $E_{0, \text { mean }}, f_{m, k}$ and $\rho_{k}$, respectively. The requirements for the strength classes are given in EN338 (factor $k_{v}=1.12$ was applied to the requirement for bending strength)

$n s$ not significant

${ }^{*} p<0.05 ;{ }^{* *} p<0.01 ; * * * p<0.001$ (significant differences between radial positions 2,3 and 4 relative to radial position 1)

${ }^{a}$ The significance of the differences in values of $f_{m, k}$ and $\rho_{k}$ between radial positions was not tested

(i.e. TR26/C14, C27/C16 and C24/C14), but this was due to higher yields in the lower strength class.

\subsection{Distortion and knot characteristics}

There were significant differences $(p<0.001$ for twist and spring; $p=0.03$ for bow) in the amount of distortion at $12 \%$ moisture content between timber from radial positions 1 and 4 (Fig. 3). The mean amount of twist over a 2-m length was $8.6 \mathrm{~mm}$ for timber from position 1, whilst it was only $3.0 \mathrm{~mm}$ for timber from position 4 . Approximately $55 \%$ of pieces cut from position 1 had values of twist in excess of $8 \mathrm{~mm}$, which is the limit given in EN14081-1 (CEN 2005).

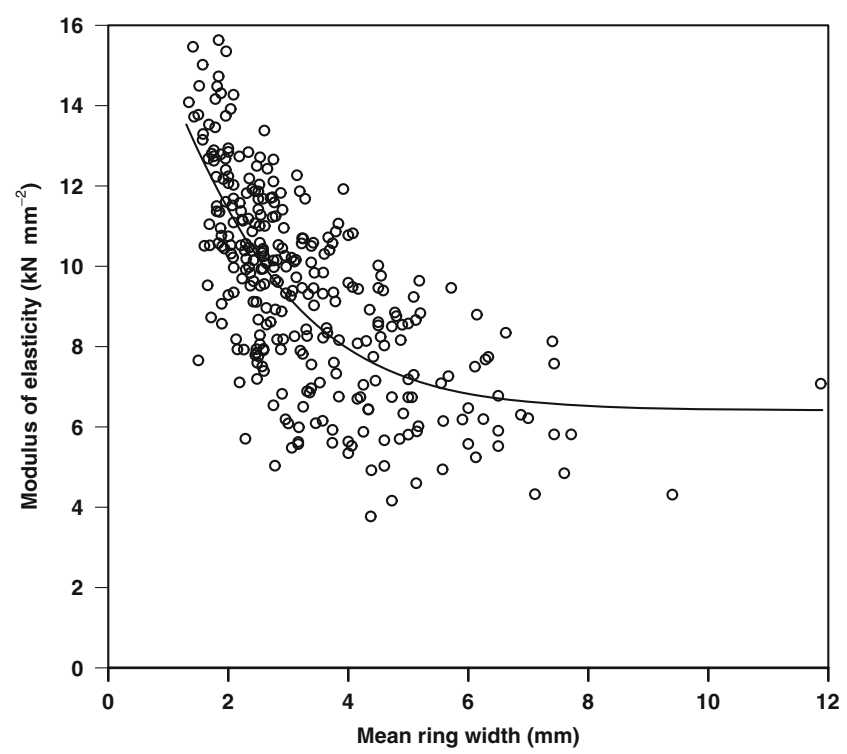

Fig. 2 Relationship between mean ring width and modulus of elasticity for all 300 pieces of timber tested. The equation for the curve fitted to the data is given in the text (Eq. 3)
In contrast, the maximum amount of twist for all timber cut from position 4 was $8.7 \mathrm{~mm}$, and fewer than $2 \%$ of pieces exceeded the limit for twist given in EN14081-1. The mean amount of spring over a 2-m length for timber cut from position $1(4.8 \mathrm{~mm})$ was more than double the mean amount for timber from position $4(2.2 \mathrm{~mm})$, whilst the amount of bow over a 2-m length was approximately $1 \mathrm{~mm}$ greater for timber cut from position 1 . Only one piece of timber had a value of spring which exceeded the limit of $12 \mathrm{~mm}$ given in EN14081-1; no piece exceeded the limit for bow of $20 \mathrm{~mm}$.

The mean diameter of knots was $19 \mathrm{~mm}$ for the 60 pieces of timber that were assessed and did not differ between radial positions $(p=0.59)$. However, timber from radial position 1 had approximately three times the number of knots (46 vs. 15) as pieces of timber from radial position 4 (Fig. 4). As a result, the average total area of knots on the four longitudinal faces of timber from position 1 was significantly higher than on timber from position $4(p<0.001)$.

\section{Discussion and conclusions}

In this study, there was a $51 \%$ increase in modulus of elasticity of structural timber cut from position 4 (outer wood) compared with timber cut from position 1 (assumed to be from the juvenile core). There was also a $61 \%$ increase in the characteristic value of bending strength (a $41 \%$ increase in the mean value) between these two radial positions, but only a $9 \%$ increase in density. This result highlights the strong influence of microfibril angle on wood stiffness as radial differences cannot be explained by density alone (Walker and Butterfield 1995). In most conifers, including Sitka spruce, microfibril angle decreases rapidly with increasing ring number from the pith (Jordan et al. 
Table 3 Results from the optimal grading of the 300 boards

\begin{tabular}{|c|c|c|c|c|c|}
\hline \multirow[t]{2}{*}{ Strength class } & \multicolumn{3}{|l|}{ Required values } & \multicolumn{2}{|l|}{ Yield (\%) } \\
\hline & $f_{m, k}\left(\mathrm{~N} \mathrm{~mm}^{-2}\right)$ & $\rho_{k}\left(\mathrm{~kg} \mathrm{~m}^{-3}\right)$ & $E_{0, \text { mean }}\left(\mathrm{kN} \mathrm{mm}^{-2}\right)$ & All timber & Without radial positions 3 and 4 \\
\hline \multicolumn{6}{|l|}{ TR26/C14 } \\
\hline TR26 & 25.3 & 370 & 10.45 & 74.0 & 52.5 \\
\hline \multirow[t]{2}{*}{$\mathrm{C} 14$} & 12.5 & 290 & 6.65 & 21.3 & 47.5 \\
\hline & & & & 95.3 & 100 \\
\hline \multicolumn{6}{|l|}{$\mathrm{C} 27 / \mathrm{C} 16$} \\
\hline $\mathrm{C} 27$ & 24.1 & 370 & 11.40 & 62.3 & 42.0 \\
\hline \multirow[t]{2}{*}{$\mathrm{C} 16$} & 14.3 & 310 & 7.60 & 23.4 & 46.4 \\
\hline & & & & 85.7 & 88.4 \\
\hline \multicolumn{6}{|l|}{$\mathrm{C} 24 / \mathrm{C} 14$} \\
\hline $\mathrm{C} 24$ & 21.4 & 350 & 10.45 & 75.7 & 55.3 \\
\hline \multirow[t]{2}{*}{$\mathrm{C} 14$} & 12.5 & 290 & 6.65 & 16.0 & 43.0 \\
\hline & & & & 91.7 & 98.3 \\
\hline $\mathrm{C} 22$ & 19.6 & 340 & 9.50 & 98.0 & 80.1 \\
\hline $\mathrm{C} 20$ & 17.9 & 330 & 9.03 & 100.0 & 92.3 \\
\hline $\mathrm{C} 18$ & 16.1 & 320 & 8.55 & 100.0 & 100.0 \\
\hline $\mathrm{C} 16$ & 14.3 & 310 & 7.60 & 100.0 & 100.0 \\
\hline
\end{tabular}

The required characteristic values for bending strength $\left(f_{m, k}\right)$, density $\left(\rho_{k}\right)$ and stiffness $\left(E_{0, \text { mean }}\right)$ are given for each strength class along with the proportion of boards that would meet these requirements. Factor $k_{v}=1.12$ has been applied to the required characteristic value for bending strength and the 0.95 factor applied to the characteristic value of modulus of elasticity

2005; McLean 2008). The increase in wood stiffness from pith to bark and between juvenile wood and mature wood is consistent with findings from numerous studies covering a wide variety of coniferous and hardwood species (e.g. Pratt 1979; Bendtsen and Senft 1986; Barrett and Kellog 1991; Kennedy 1995; Kliger et al. 1995; Walker and Nakada
Fig. 3 Comparison of the magnitude of spring, twist and bow of structural timber cut from radial positions 1 and 4
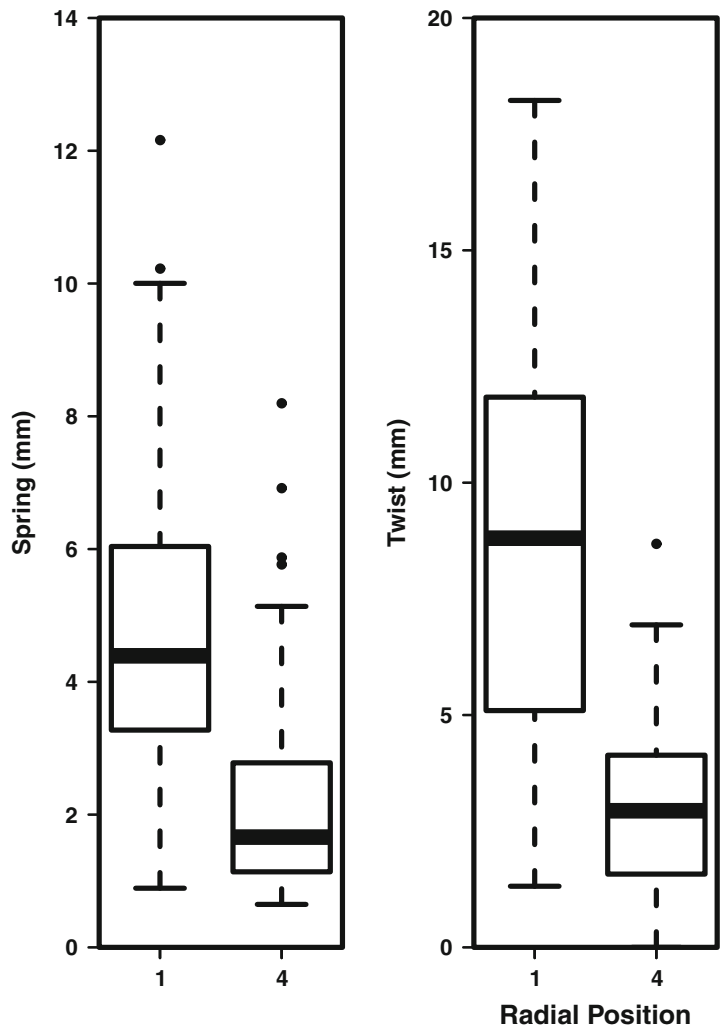
Fig. 4 Comparison of knot characteristics measured on structural timber cut from radial positions 1 and 4 in the butt logs

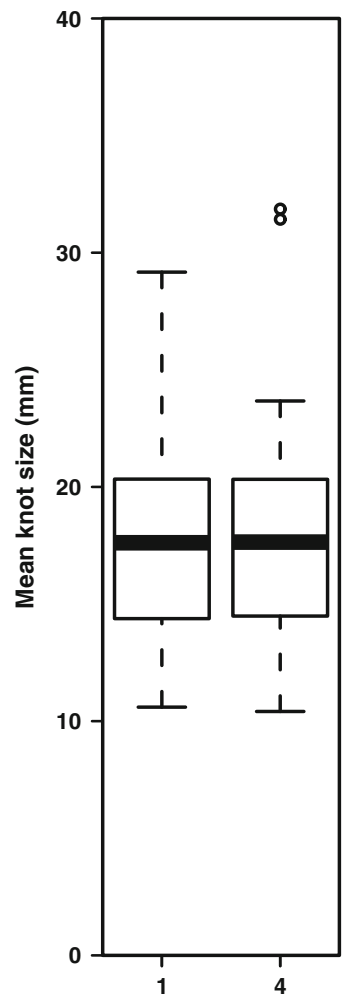

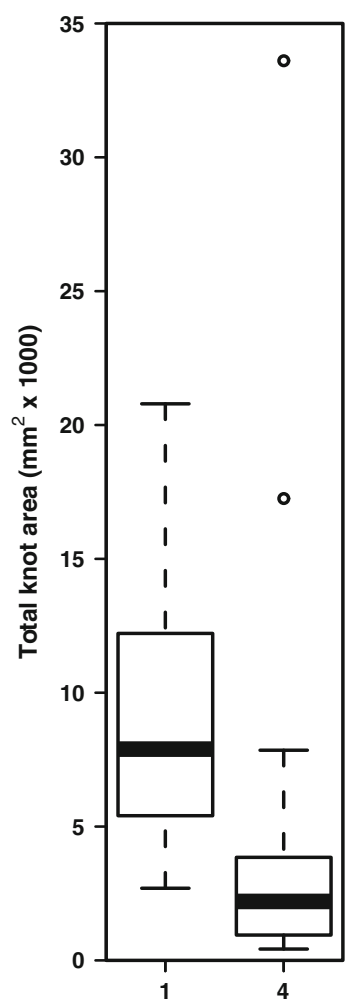

1999; Bao et al. 2001; Koponen et al. 2005). The increase in timber strength may also be partly attributable to the reduction in knot content between radial positions 1 and 4 as knots are considered to be one of the main strength-reducing defects in timber (Forest Products Laboratory 2010).

Wood from the juvenile core of a tree has higher longitudinal shrinkage and lower transverse shrinkage due to its high microfibril angle (Ilic et al. 2003). This higher longitudinal shrinkage, coupled with a higher spiral grain angle in the juvenile core, means that timber cut from this region is more likely to distort (especially twist) than timber cut from the mature outerwood (Brazier 1985). This was particularly apparent in this study where the mean amount of twist of timber cut from the mature outerwood (position 4) was approximately one third that measured on timber cut from the juvenile core (position 1). This reduction in twist with increasing radial position is consistent with the finding of Perstorper et al. (1995) who investigated the effect of radial position on the distortion of Norway spruce (Picea abies (L.) Karst) timber. Many of the applications that require higher strength timber such as trussed rafters also have strict limits on timber distortion, so the lower amounts of distortion associated with the higher stiffness timber from the outside of the tree would mean that this timber would be potentially suited to such applications.

The age at which the transition from juvenile wood to mature wood occurs varies among and between species and also depends on the characteristics used to define juvenile wood. If the point at which the radial variation in wood density stabilises is used to define the boundary between juvenile and mature wood, then this can range from ring 8 up to ring 35 (Bendtsen and Senft 1986; Kennedy 1995). In Sitka spruce, Brazier and Mobbs (1993) have used an apparently arbitrary definition of ring 12 to denote the boundary of the juvenile wood zone. Regardless of the age that this transition from juvenile wood to mature wood occurs, increasing the rotation length of a stand will reduce the proportion of juvenile wood within a tree. In general, this has been shown to increase the overall mechanical properties of the timber cut from these trees as the proportion of timber cut from outside the juvenile core increases (e.g. Bilbis et al. 1993; Duchesne 2006). Whilst the average $\mathrm{MOE}_{\mathrm{PB}}$ of timber tested in this study $\left(9.41 \mathrm{kN} \mathrm{mm}^{-2}\right)$ was substantially higher than the $7.52 \mathrm{kN} \mathrm{mm}^{-2}$ determined for timber cut from a 37-year-old Sitka spruce progeny trial growing nearby in Kershope Forest (Moore et al. 2009), the average MOE for the whole population of timber cut from Birkley Wood is likely to be higher still as timber from radial positions 3 and 4 will constitute a greater proportion of the overall volume of wood than of the sample that was tested. Therefore, the optimal yields of higher strength class timber could be even higher than those calculated in this study. On the other hand, actual yields when timber is graded in practice are less than the optimal yield as grading machines are not able to perfectly measure the gradedetermining properties of each piece of timber. 
Whilst it appears that longer rotations will result in timber with improved mechanical properties (possibly meeting the requirements for the $\mathrm{C} 24$ strength class) and a lower propensity to distort, this course of action is unlikely to be economic. In order to offset the costs of growing the trees for an additional 35-40 years, there would need to be a considerable price premium for higher strength classes of timber. At present, this premium does not exist, with $\mathrm{C} 16$ and $\mathrm{C} 24$ grade structural timber selling for approximately the same price in Great Britain. Unless this situation changed or there was a shift in end-user preference towards C24 grade timber, it is unlikely that rotation length in evenaged British Sitka spruce forests will increase. Increasing rotation lengths also make forests more vulnerable to wind damage as the trees will be taller and the time they are exposed to the hazard also increases (Quine et al. 1995). The more likely scenario is that small groups of older trees are retained as part of a continuous cover system, although trees grown under these conditions may have somewhat different wood properties from the same aged tree grown in an even-aged stand (Macdonald et al. 2010).

In conclusion, this study has yielded a considerable amount of information on the radial variation in wood properties within Sitka spruce trees and the impact of this variation on the properties of structural timber. This information can be used to inform forest managers and timber processors about the consequences of various courses of action on timber properties, not only decisions about rotation length but also various other decisions around silvicultural and processing options. With a shift towards continuous cover forestry on some sites, knowledge about the wood properties of older legacy trees that could exist under this type of management will be a useful addition to existing knowledge (e.g. Macdonald et al. 2010) about the implications of this type of management on timber quality.

\begin{abstract}
Acknowledgements Dr Chris Quine from Forest Research alerted us to the potential opportunity to study the wood properties of older trees at Birkley Wood. The Kielder Forest District staff, in particular Graham Gill, David Woodhouse and Simon Banks, allowed us access to the stand and arranged assistance with felling and processing of the trees. Francis Wilbur from James Jones \& Sons sawmills arranged the processing, drying and grading of the timber. Greg Searles assisted with the fieldwork and the mechanical testing. Martin Bacher from MiCROTEC assisted with analysis of the strength grading data. Dr. Barry Gardiner from Forest Research assisted with developing the original project proposal and, along with Dr. Dan Ridley-Ellis, Dr Dave Auty and Elspeth Macdonald, provided comments on an earlier version of the manuscript. Funding for this study was provided by the Scottish Funding Council and the Scottish Forestry Trust.
\end{abstract}

\section{References}

Bao FC, Jiang ZH, Jiang XM, Lu XX, Luo XQ, Zhang SY (2001) Differences in wood properties between juvenile and mature wood in 10 species grown in China. Wood Sci Technol 35:363375

Barrett JD, Kellog RM (1991) Bending strength and stiffness of second-growth Douglas-fir dimension lumber. Forest Prod J 41:35-43

Bendtsen BA, Senft J (1986) Mechanical and anatomical properties in individual growth rings of plantation-grown eastern cottonwood and loblolly pine. Wood Fiber Sci 18:23-38

Bilbis EJ, Brinker R, Carino HF, McKee CW (1993) Effects of stand age on flexural properties and grade compliance of lumber from loblolly pine plantation timber. Forest Prod J $43: 23-28$

Brazier JD (1985) Juvenile wood. In: Kuchera LJ (ed) Xylorama trends in wood research. Birkhauser, Basel

Brazier JD, Mobbs ID (1993) The influence of planting distance on structural wood yields of unthinned Sitka spruce. Forestry 66:333-352

CEN (1997) Round and sawn timber-method of measurement of features. EN1310:1997. European Committee for Standardisation, Brussels, $15 \mathrm{pp}$

CEN (2002) Moisture content of a piece of sawn timber - part 1: Determination by oven dry method. EN13183-1:2002. European Committee for Standardisation, Brussels, $5 \mathrm{pp}$

CEN (2003) Timber structures - structural timber and glued laminated timber-determination of some physical and mechanical properties. EN408:2003. European Committee for Standardisation, Brussels, $13 \mathrm{pp}$

CEN (2005) Timber structures - Strength graded structural timber with rectangular cross section. Part 1: General requirements. EN 14081-1:2005. European Committee for Standardisation, Brussels, $29 \mathrm{pp}$

CEN (2009) Structural timber-Strength classes. EN338:2009. European Committee for Standardisation, Brussels, $10 \mathrm{pp}$

CEN (2010a) Structural timber - determination of characteristic values of mechanical properties and density. EN384:2010. European Committee for Standardisation, Brussels, $19 \mathrm{pp}$

CEN (2010b) Timber structures - strength graded structural timber with rectangular cross section. Part 2: Machine grading; additional requirements for initial type testing. EN 14081-2:2010. European Committee for Standardisation, Brussels, $21 \mathrm{pp}$

Clark A III, McAlister RH, Saucier JR, Reitter K (1996) Effect of rotation age on lumber grade, yield, and strength of unthinned loblolly pine. Forest Prod J 46:63-68

Cown DJ, McConchie DL (1982) Rotation age and silvicultural effects on wood properties of four stands of Pinus radiata. N Z J Forestry Sci 12:71-85

Cown DJ, Ball RD, Riddell M, Wilcox P (2002) Microfibril angle in plantation pine: distribution and influence on product performance. IUFRO Working Party S5.01.04 Workshop, Harrison Hot Springs, Canada, September 2002

Duchesne I (2006) Effect of rotation age on lumber grade yield, bending strength and stiffness in Jack pine (Pinus banksiana Lamb.) natural stands. Wood Fiber Sci 38:84-94

Evans R, Ilic J (2001) Rapid prediction of wood stiffness from microfibril angle and density. Forest Prod J 51:53-57

Forest Products Laboratory (2010) Wood handbook: wood as an engineering material. Gen. Tech. Rep. FPL-GTR-113. USDA Forest Service, Forest Products Society, Madison

Forestry Commission (2010) Forestry statistics 2010 - a compendium of statistics about woodland, forestry and primary wood processing in the United Kingdom, 208 pp. http://www.forestry.gov.uk/ statistics

Ilic J, Northway R, Pongracic S (2003) Juvenile wood characteristics, effects and identification: literature review. FWPRDC Report PN02.1907. Forest and Wood Products Research and Development Corporation, Australia 
ISO (1975) Wood - determination of density for physical and mechanical tests. ISO 3131: 1975. International Organization for Standardisation, Geneva

Johansson M, Perstorper M, Kliger R (2001) Distortion of Norway spruce timber-part 2. Modelling twist. Holz Roh Werkst 59:155-162

Jordan L, Daniels RF, Clark A, He R (2005) Multilevel nonlinear mixed-effects models for the modeling of earlywood and latewood microfibril angle. Forest Sci 51:357-371

Kennedy RW (1995) Coniferous wood quality in the future: concerns and strategies. Wood Sci Technol 29:321-338

Kliger IR, Perstorper M, Johansson G, Pellicane PJ (1995) Quality of timber products from Norway spruce - part 3. Influence of spatial position and growth characteristics on bending stiffness and strength. Wood Sci Technol 29:397-410

Koponen T, Karppinen T, Hæggström, Saranpää P, Serimaa R (2005) The stiffness modulus in Norway spruce. Holzforchung 59:451-455

Lachenbruch B, Moore JR, Evans R (2011) Radial variation in wood structure and function in woody plants, and hypotheses for its occurrence. In: Meinzer FC, Dawson T, Lachenbruch B (eds) Size and Age-Related Variation in Tree Structure and Function. Springer Series in Tree Physiology

Larson PR, Kretschmann DE, Clark A III, Isebrands JG (2001) Formation and properties of juvenile wood in southern pines: a synopsis. Gen. Tech. Rep. FPL-GTR-129. U.S. Department of Agriculture, Forest Service, Forest Products Laboratory, Madison, $42 \mathrm{pp}$

Macdonald E, Hubert J (2002) A review of the effects of silviculture on timber quality of Sitka spruce. Forestry 75:107-138

Macdonald E, Gardiner B, Mason W (2010) The effects of transformation of even-aged stands to continuous cover forestry on conifer $\log$ quality and wood properties in the UK. Forestry $83: 1-16$

McLean JP (2008) Wood properties of four genotypes of Sitka spruce. $\mathrm{PhD}$ thesis, Department of Analytical and Environmental Chemistry, University of Glasgow, UK, 269 pp

McLean JP, Evans R, Moore JR (2010) Predicting the longitudinal modulus of elasticity of Sitka spruce from cellulose orientation and abundance. Holzforschung 64:495-500

Miller KF (1985) Windthrow hazard classification. Forestry Commission Leaflet No. 85. HMSO, London
Mochan S, Connolly T (2006) The effect of windblow on the timber quality of Sitka spruce. Scott Forestry 60:15-20

Moore JR, Mochan SJ, Brüchert F, Hapca AI, Ridley-Ellis DJ, Gardiner BA, Lee SJ (2009) Effects of genetics on the wood properties of Sitka spruce growing in the United Kingdom: bending strength and stiffness of structural timber. Forestry 82:491-501

Ormarsson S, Cown DJ (2005) Moisture-related distortion of boards and wooden products of radiata pine: comparison with Norway spruce: Wood Fiber Sci 37:424-436

Perstorper M, Pellicane PJ, Kliger IR, Johansson G (1995) Quality of timber products from Norway spruce. Part 2: Influence of spatial position and growth characteristics on warp. Wood Sci Technol 29:339-352

Pinheiro JC, Bates DM (2000) Mixed-effects models in S and S-Plus. Springer, New York, $528 \mathrm{pp}$

Pratt JE (1979) Fomes annosus butt-rot of Sitka spruce: II. Loss of strength of wood in various categories of rot. Forestry 52:31-45

Quine CP, Malcolm DC (2007) Wind-driven gap development in Birkley Wood, a long-term retention of planted Sitka spruce in upland Britain. Can J Forest Res 37:1787-1796

Quine C, Coutts M, Gardiner B, Pyatt G (1995) Forests and wind: management to minimise damage. Bulletin 114. Forestry Commission, Edinburgh, $24 \mathrm{pp}$

R Development Core Team (2010) R: a language and environment for statistical computing. R Foundation for Statistical Computing, Vienna, Austria. ISBN 3-900051-07-0. http://www.R-project.org

Seeling U, Merforth C (2000) FRITS - a new equipment to measure distortion. Holz Roh Werkst 58:338-339

Walker JCF (2006) Primary wood processing: principles and practice, 2nd edn. Springer, Dordrecht, $596 \mathrm{pp}$

Walker JCF, Butterfield BG (1995) The importance of microfibril angle for the processing industries. New Zeal J Forest 40:34 40

Walker JCF, Nakada R (1999) Understanding corewood in some softwoods: a selective review on stiffness and acoustics. Int Forest Rev 1:251-259

Xu P, Walker JCF (2004) Stiffness gradients in radiata pine trees. Wood Sci Technol 38:1-9

Zobel BJ, Sprague JR (1998) Juvenile wood in forest trees. Springer, Berlin 